nidas numa sala de aula da PUC-SP. Era um pequeno passo, mas importante. Falou-se da criação de um Boletim, que foi a semente de nossa revista Psicologia Social $e$ Sociedade. Mas foi uma articulação a mais. De fora da PUC, apenas a Ângela Caniato e eu. E desde então, nunca deixei de receber bilhetes seus articulando atividades e encontros. Em alguns encontros, éramos uma dezena. Mas ninguém consegue segurar o Zeitgeist, o espírito. No encontro da ABRAPSO em Belo Horizonte, já houve um crescimento enorme. E a Abrapso faz hoje encontros de mais de 3.000 pessoas. Mas precisa coragem e pertinácia. Cansei de ver Sílvia sentada numa sala de aula, nesses encontros, com um pequeno grupo de pessoas, discutindo, falando, incentivando. Para todos tinha um carinho. E como isso frutificou.

3. Termino ressaltando um último ponto que considero central em Sílvia, o que eu chamaria de sua "teoria do conhecimento". Nisso também vi como ela cresceu. Vendo sua produção, percebe-se que Sílvia foi compreendendo que o saber, o conhecimento, é muito mais do que um conhecimento cognitivo, lógico. Pelo contrário, ele é polifásico, elástico, múltiplo. Inclui a dimensão da emoção, da paixão e, principalmente, da ação. Costumava dizer que a psicologia começou a se interessar pelo pensar, passando ao falar, depois ao agir e que com dificuldade chegava ao sentir. O livro Psicologia das Emoções lida com essa problemática.

Até a década de 1980, o conhecimento reconhecido como válido nas academias era nossa herança cartesiana, um conhecimento racional e lógico e individual. Tudo o resto eram crenças, superstições, mitos, etc. Ora, o saber popular, o saber do senso comum, por estar impregnado e ser constituído por outras dimensões, além do racional e o lógico, não era levado em consideração. Isso levava à diminuição, quando não ao desprezo, de outros tipos de saberes. Mas isso não é tudo: essa hierarquia de saberes conduzia aa estabelecimento de uma hierarquia na sociedade. Então temos os que verdadeiramente sabem, que são os intelectuais, homens e mulheres da academia, que eram verdadeiramente os bons, os importantes, os que sabiam. E através dessa prática, sem muitas vezes se darem conta, reproduziam as diferenças sociais, levando a uma discriminação contra grupos e saberes populares. O que fica claro na teoria e na prática de Sílvia Lane é que os saberes são também práticas e quando restritos à esfera do intelectual, levam facilmente à alienação de uns às custas da dominação de outros.

Essas considerações e notas são muito pessoais e peço que me desculpem isso. Mas era assim que era também Sílvia. Simples e amiga. Ela continua conosco, com suas práticas, entusiasmando aos amigos de ontem e os jovens de hoje. Prova disso é o fato do diretório acadêmico da Faculdade de Psicologia de Blumenau se denominar Sílvia Lane.

Pedro Guareschi é formado em Teologia, Letras e Filosofia; pós-graduado em Sociologia. Professor da Pontifícia Universidade Católica do Rio Grande do Sul (PUC-RS). Endereço para correspondência: PUC-RS, Programa de Graduação em Psicologia, Avenida Ipiranga, 6681, Parthenon, Caixa Postal 1429, Porto Alegre, RS, 90681-900. guaresch@pucrs.br

\title{
LIDERANÇA POLÍTICA E INTELECTUAL
}

\author{
Alberto Abib Andery \\ Paróquia Nossa Senhora do Carmo, São Paulo, Brasil
}

Apresento meu depoimento pessoal sobre a saudosa Dra. Sílvia T. Maurer Lane.

Tive a grata oportunidade de trabalhar quase que cotidianamente com ela na Pontifícia Universidade Católica de São Paulo (PUC-SP), como professor do Departamento de Psicologia Social e também, na Diretoria do Centro de Ciências Humanas. Foi um longo período, desde 1970 até 1987, quando me aposentei e saí da Universidade Católica de São Paulo. Meu depoimento, portanto, abrange esse período.
Participei a seu lado de vários encargos importantes nos anos setenta-oitenta. O primeiro deles foi na comissão diretora da nova Faculdade de Psicologia da PUCSP, surgida da fusão das antigas Faculdades de Filosofia, Ciências e Letras: São Bento e Sedes Sapientiae, que foram unidas por exigência da Lei de reforma universitária, numa única e nova Faculdade de Psicologia, com vários novos Departamentos.

Sílvia, eu e vários colegas docentes compusemos o novo Departamento de Psicologia Social cuja primeira 
tarefa foi enfrentar os desafios de uma nova definição da psicologia social face à crise do modelo funcionalista europeu e norte-americano.

Participamos também, nos anos setenta, da resistência dentro da PUC-SP à ditadura militar e à invasão do campus da Monte Alegre pela polícia em 1977. Esse grave incidente gerou, como resposta vigorosa dos professores, a fundação da Associação dos Professores da PUC-SP (APROPUC) e conduziu a universidade católica à prática da democracia interna com a eleição direta da Reitoria pelos professores, funcionários e alunos. Sílvia destacou-se na liderança do movimento dos Professores.

$\mathrm{Na}$ área docente, desde 1977 fui professor no núcleo de Psicologia na Comunidade, criado como espaço de estágio optativo para alunos do curso de Psicologia (nono e décimo período). Esse núcleo visava a aproximação entre os futuros profissionais psicólogos e a população operária e proletária nos extremos da periferia da grande São Paulo. Os estágios eram desenvolvidos no Jardim Santo Antônio, em Osasco, com a ajuda de uma equipe multiprofissional. Contamos também com a colaboração da colega Professora Odete Pinheiro. Sílvia Lane, na chefia do Departamento de Psicologia Social e depois Diretora do Centro de Ciências Humanas, deu apoio entusiasmado e críticas construtivas ao Projeto, enquanto ele durou.

Participei também com Sílvia e outros/as colegas da Psicologia Social da fundação da Associação Brasileira de Psicologia Social (ABRAPSO), em 1980, e trabalhei na edição dos Boletins da ABRAPSO com a Professora Brônia Liebsny até 1987, quando, por aposentadoria, sai da PUC-SP.

A convivência cotidiana nesse período com Sílvia fez-me descobrir sua pessoa extremamente afável e ética, sua capacidade acadêmica muito criativa e inovadora e mais, sua habilidade de liderança política e intelectual.

Mas a grandeza excepcional de Sílvia só vim a entendê-la em toda sua extensão muito recentemente, através do livro da Dra. Bader Sawaia sobre Sílvia Lane, publicado pela Imago Editora, em 2002, volume oito da coleção Pioneiros da Psicologia patrocinado pelo Conselho Federal de Psicologia.

Reconheço que, apesar de minha longa convivência com ela na PUC-SP, fiquei admirado pela sua biografia acadêmica, sua produção de idéias, de livros e escritos e o número e qualidade de novos pesquisadores de mestrado e doutorado que Sílvia apoiou e conduziu durante sua carreira universitária. Sou grato à Dra. Bader
Sawaia pela sua sagacidade em captar e expor no seu livro acima citado o roteiro de produção e ressonâncias múltiplas da passagem de Sílvia pela universidade brasileira e latino-americana.

Refletindo hoje sobre sua saudosa pessoa e obra acadêmica, reconheço plenamente sua importância na transformação da práxis do psicólogo social no Brasil, nestes 40 anos de magistério enquanto filósofa, pesquisadora social e psicóloga eminente que foi Dra. Sílvia Lane na PUC-SP.

Neste depoimento, fico feliz por poder, mais uma vez, manifestar minha admiração pela pessoa e pela obra gigantesca em todos os sentidos da querida Mestra e amiga pessoal que tanto me incentivou e ajudou no departamento de Psicologia Social e no Centro de Ciências Humanas da PUC-SP.

Sua memória é inspiradora, para todos nós que com ela convivemos, para prosseguir sua trilha na construção do homem ou mulher em movimento, como ela própria denominou a aventura humana individual e coletiva, no título do seu livro, para mim muito caro, que organizou e conosco escreveu, em 1980.

Que Deus a tenha viva e presente na vida e na memória dos que como eu tivemos a felicidade de conhecêla e estimá-la como querida amiga e Mestra.

São Paulo, 29 de maio de 2007.

Alberto Abib Andery é psicólogo. Ex-professor do Departamento de Psicologia Social da Pontifícia Universidade Católica de São Paulo (PUC-SP). Padre da paróquia Nossa Senhora do Carmo. Endereço para correspondência: Rua Artur Farjado, 535, São Paulo, SP, 0296-000. www.arquidiocese-sp.org.br 